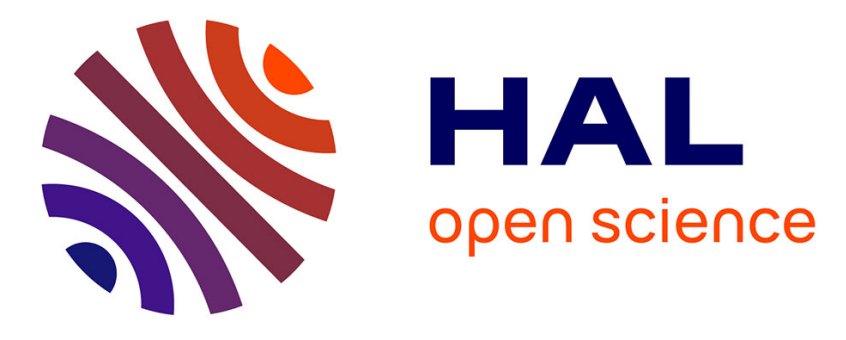

\title{
N-Glycosylation with Sulfoxide Donors for the Synthesis of Peptidonucleosides
}

Margaux Beretta, Emilie Rouchaud, Lionel Nicolas, Jean-Pierre Vors, Thomas Dröge, Mazen Es-Sayed, Jean-Marie Beau, Stéphanie Norsikian

\section{- To cite this version:}

Margaux Beretta, Emilie Rouchaud, Lionel Nicolas, Jean-Pierre Vors, Thomas Dröge, et al.. NGlycosylation with Sulfoxide Donors for the Synthesis of Peptidonucleosides. Organic \& Biomolecular Chemistry, 2021, 10.1039/d1ob00493j . hal-03292018

\section{HAL Id: hal-03292018 https://hal.science/hal-03292018}

Submitted on 20 Jul 2021

HAL is a multi-disciplinary open access archive for the deposit and dissemination of scientific research documents, whether they are published or not. The documents may come from teaching and research institutions in France or abroad, or from public or private research centers.
L'archive ouverte pluridisciplinaire $\mathbf{H A L}$, est destinée au dépôt et à la diffusion de documents scientifiques de niveau recherche, publiés ou non, émanant des établissements d'enseignement et de recherche français ou étrangers, des laboratoires publics ou privés. 
Received 00th January 20xx Accepted 00th January 20xx

DOI: $10.1039 / \mathrm{x} 0 \mathrm{x} \times 00000 \mathrm{x}$

\title{
$N$-Glycosylation with Sulfoxide Donors for the Synthesis of Peptidonucleosides
}

\author{
This article is dedicated to the memory of our esteemed colleague Dr. Mazen Es-Sayed
}

Margaux Beretta, ${ }^{a}$ Emilie Rouchaud, ${ }^{a}$ Lionel Nicolas, ${ }^{\mathrm{b}}$ Jean-Pierre Vors, ${ }^{\mathrm{b}}$ Thomas Dröge, ${ }^{\mathrm{c}}$ Mazen Es-Sayed, ${ }^{\mathrm{c}}$ Jean-Marie Beau, *a,d and Stéphanie Norsikian *a

\begin{abstract}
The synthesis of glycopyranosyl nucleosides modified in the sugar moiety is less frequently explored, notably because of a lack of a reliable method to glycosylate pyrimidine bases. Herein we report a solution in the context of the synthesis of peptidonucleosides. They were obtained after glycosylation of different pyrimidine nucleobases with glucopyranosyl donors carrying an azide group at the $\mathrm{C} 4$ position. A methodological study involving different anomeric leaving groups (acetate, phenylsulfoxide and ortho-hexynylbenzoate) showed that a sulfoxide donor in combination with trimethylsilyl triflate as the promoter led to the best yields.
\end{abstract}

\section{Introduction}

Fungicides represent a class of pesticides used to prevent the development of a fungus in the plant and / or to fight a fungal infection caused by a pathogen. ${ }^{1}$ Their use has become essential over time to avoid contamination of whole crops and improve agricultural yields in a context of increasing urbanization that continues to decrease the area of cultivable land. ${ }^{2}$ The continuous use of agrochemicals has led to the development of pest resistance to active substances, which makes some pesticides ineffective. ${ }^{3}$ Thus, finding new structural motifs with new antifungal modes of action to fight against pathogens is essential to circumvent resistances. Natural products remain an important source of inspiration for the discovery of new active molecules. Among them gougerotin, isolated for the first time in 1962 from strains of Streptomyces gougerotii, ${ }^{4}$ caught the attention of researchers. ${ }^{5}$ This peptidylnucleoside consists of a glucan-type pyranose saccharide motif that has a carboxamide group at the 6-position. It is also substituted at the 4-position by a dipeptide made of $\mathrm{D}$ -

a. Université Paris-Saclay, CNRS, Institut de Chimie des Substances Naturelles, UPR 2301, 91198, Gif-sur-Yvette, France..

b. Bayer CropScience, Disease Control Chemistry, Centre de Recherche de La Dargoire, 14 impasse Pierre Baizet, 69009 Lyon, France

c. Bayer CropScience, Disease Control Chemistry, Alfred-Nobel-Str. 50, 40789 Monheim am Rhein, Germany

d. Institut de Chimie Moléculaire et des Matériaux d'Orsay (ICMMO), UMR 8182, Univ. Paris-Sud and CNRS, Université Paris-Saclay, F-91405 Orsay, France

Electronic Supplementary Information (ESI) available: [details of any supplementary information available should be included here]. See DOI: $10.1039 / \mathrm{x} 0 \mathrm{xx} 00000 \mathrm{x}$

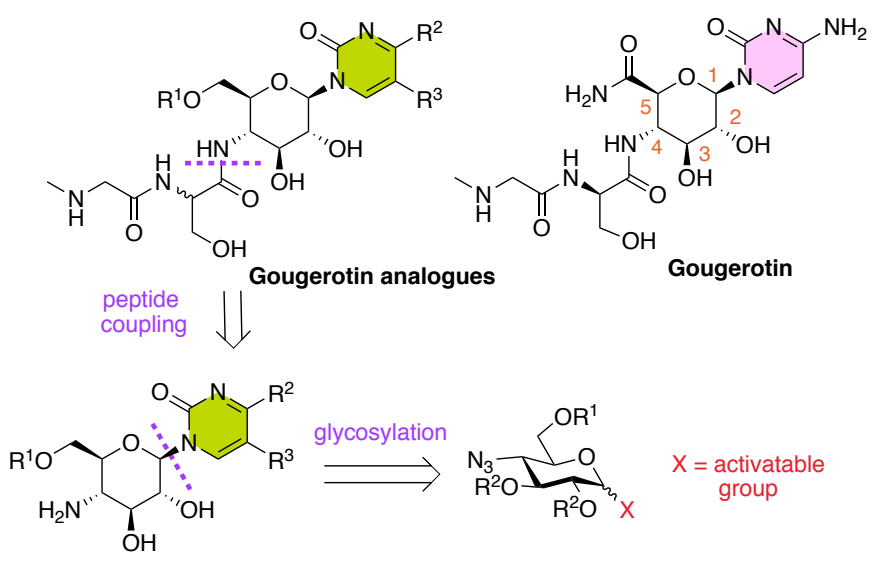

Figure 1. Retrosynthetic scheme of gougerotin analogues

serine and sarcosine and $\mathrm{N}$-linked at the anomeric position by a cytosine base. Since its discovery, gougerotin has been the subject of three total syntheses, including two described in the $1970 \mathrm{~s}^{6}$ and a more recent one in 2005 using solid- and solutionphase methodology. ${ }^{7}$ Gougerotin has a very broad spectrum of biological activities: antiviral, ${ }^{8}$ antifungal, ${ }^{5}$ antiparasitic and antibacterial ${ }^{9}$ by inhibiting protein synthesis in procaryotic and eucaryotic systems. It is active on several varieties of plants whether in preventive or curative tests but its phytotoxicity limits its direct use on plants. ${ }^{10}$ In order to optimize its crop specificity, we were interested in the preparation of a few gougerotin analogues. The main modifications will concern the replacement of the natural nucleic base by other pyrimidine bases while preserving the glucopyranosyl skeleton of the parent molecule (Figure 1). The carboxamide function at C5 
will also be replaced by a free hydroxymethyl group. To access these compounds, different bases will first be glycosylated with a donor carrying an azide group at the $\mathrm{C} 4$ position. Following this glycosylation step, the azide will be reduced to the corresponding amine allowing a dipeptide coupling. A potential impact of the dipeptide motif on the bioactivity will also be studied with the synthesis of compounds comprising L-serine instead of D-serine or a modified peptide.

\section{Results and discussion}

First of all, we prepared anomeric acetate donor 5, which is the most conventionally activatable donor used to synthesize nucleoside derivatives under Vorbrüggen glycosylation conditions (Scheme 1). ${ }^{11}$ Methyl $\alpha$-D-galactopyranoside 1a was first protected as a 4,6-benzylidene acetal to yield the corresponding product, which was esterified with acetic anhydride in pyridine. Compound 2a was then engaged in a reductive opening reaction of the 4,6- $O$-benzylidene acetal to lead to galactopyranoside 3a having a free hydroxyl at position 4. Best results for this step were obtained using triethylsilane ( 2.5 eq.) in combination with triflic acid (2 eq.) as described by Sakagami and Hamana. ${ }^{12}$ Since we also observed the formation of the corresponding 4- $O$-triethylsilyl ether adduct, the reaction mixture was further treated with tetrafluoroboric acid to furnish the desired alcohol 3a in $63 \%$ yield. The latter was then reacted with $\mathrm{Tf}_{2} \mathrm{O}$ in the presence of pyridine to form the triflate in the 4-position, that was displaced by $\mathrm{NaN}_{3}$ with inversion of configuration leading to 4-azido-4-deoxy glucopyranoside adduct 4a. A final acetolysis step led to donor 5 as a mixture of anomers $(\alpha / \beta=8: 2)$.

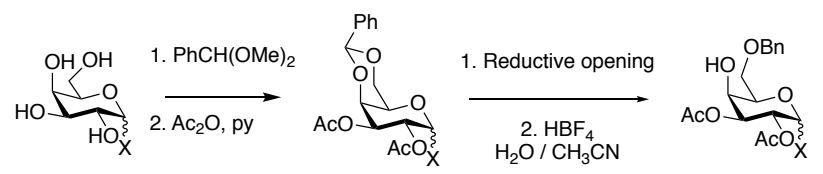

$\begin{array}{lll}\text { 1a }(X=\alpha-\mathrm{OMe}) & \text { 2a }(90 \%, X=\alpha-\mathrm{OMe}) & \text { 3a }(63 \%, X=\alpha-\mathrm{OMe}) \\ \mathbf{1 b}(X=\beta-\mathrm{SPh}) & \text { 2b }(73 \%, X=\beta-\mathrm{SPh}) & \text { 3b }(88 \%, X=\beta-\mathrm{SPh})\end{array}$

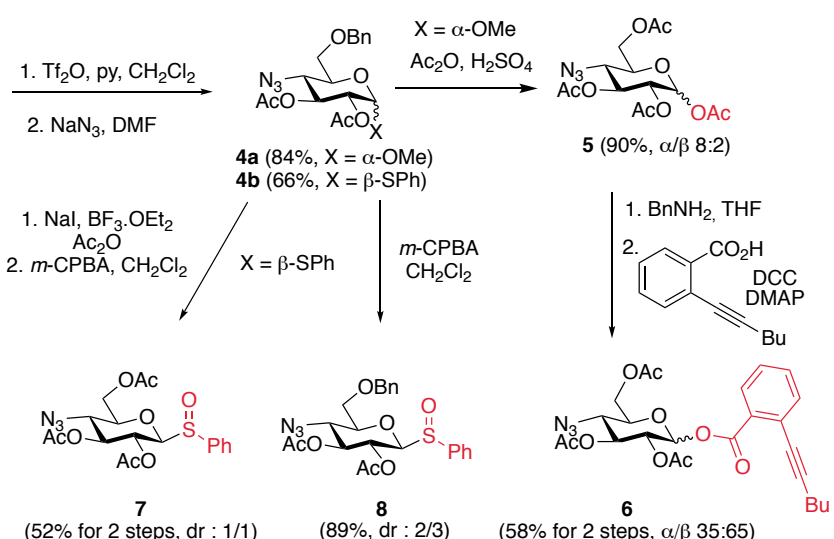

Scheme 1. Preparation of different donors 5-8. Conditions for the reductive opening: with 2a (X = $\alpha$-OMe) $\mathrm{Et}_{3} \mathrm{SiH}$ (2.5 eq.), TfOH (2 eq.) in $\mathrm{CH}_{3} \mathrm{CN}$, with $\mathbf{2 b}(\mathrm{X}=\beta-\mathrm{SPh}) \mathrm{Et}_{3} \mathrm{SiH}$ (1 eq.), cat. $\mathrm{Cu}(\mathrm{OTf})_{2}$ in $\mathrm{CH}_{3} \mathrm{CN}$

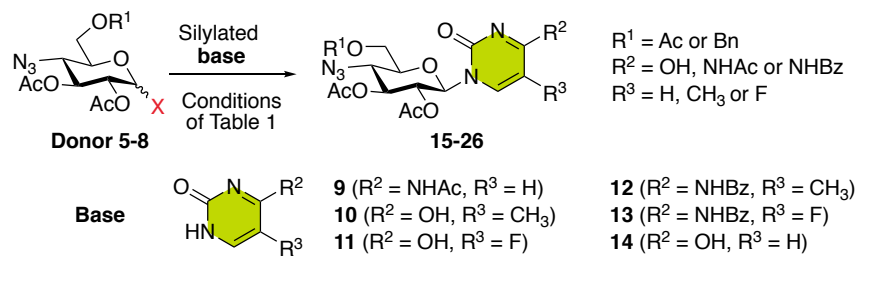

Obtained Compounds

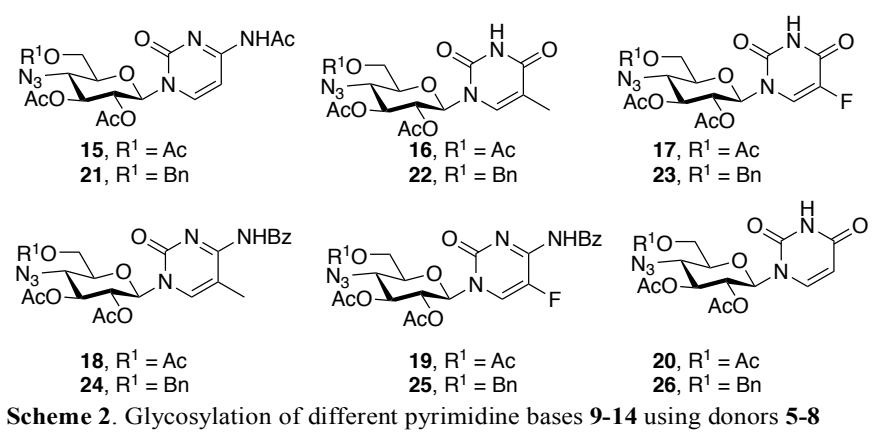

Table 1. $N$-Glycosylation conditions of different pyrimidine bases

\begin{tabular}{|c|c|c|c|c|}
\hline entry & Donor & Base $^{\mathrm{a}}$ & Conditions ${ }^{b}$ & $\begin{array}{c}\text { Compound, } \\
\text { Yield (\%) }\end{array}$ \\
\hline 1 & 5 & 9 & TMSOTf (1.5 eq.) & $\mathbf{1 5}, 36$ \\
\hline 2 & 5 & 9 & $\mathrm{SnCl}_{4}(3 \text { eq. })^{\mathrm{c}}$ & 15,69 \\
\hline 3 & 5 & 10 & $\mathrm{SnCl}_{4}$ (3 eq.) & 16,74 \\
\hline 4 & 5 & $11^{\mathrm{d}}$ & TMSOTf (1.5 eq.) & 17,71 \\
\hline 5 & 5 & 12 & $\mathrm{SnCl}_{4}$ (3 eq.) & $\mathbf{1 8}, 45$ \\
\hline 6 & 5 & 13 & $\mathrm{SnCl}_{4}$ (3 eq.) & $\mathbf{1 9}, 51$ \\
\hline 7 & 5 & $14^{\mathrm{d}}$ & TMSOTf (1.5 eq.) & $\mathbf{2 0}, 25$ \\
\hline 8 & 6 & $9^{e, f}$ & $\mathrm{Ph}_{3} \mathrm{PAuNTf}_{2}(10 \mathrm{~mol} \%)$ & $\mathbf{1 5}, 49$ \\
\hline 9 & 6 & $10^{\mathrm{e}, \mathrm{f}}$ & $\mathrm{Ph}_{3} \mathrm{PAuNTf}_{2}(10 \mathrm{~mol} \%)$ & 16,48 \\
\hline 10 & 6 & $11^{\mathrm{f}}$ & $\mathrm{Ph}_{3} \mathrm{PAuNTf}_{2}(10 \mathrm{~mol} \%)$ & 17,40 \\
\hline 11 & 6 & $12^{\mathrm{e}, \mathrm{f}}$ & $\mathrm{Ph}_{3} \mathrm{PAuNTf}_{2}(10 \mathrm{~mol} \%)$ & 18,30 \\
\hline 12 & 6 & $13^{\mathrm{f}}$ & $\mathrm{Ph}_{3} \mathrm{PAuNTf}_{2}(10 \mathrm{~mol} \%)$ & 19,9 \\
\hline 13 & 6 & $14^{\mathrm{e}, \mathrm{f}}$ & $\mathrm{Ph}_{3} \mathrm{PAuNTf}_{2}(10 \mathrm{~mol} \%)$ & $\mathbf{2 0}, 78$ \\
\hline 14 & 7 & 9 & TMSOTf (1.5 eq.) & 15,95 \\
\hline 15 & 7 & 10 & TMSOTf (1.5 eq.) & 16,89 \\
\hline 16 & 7 & 11 & TMSOTf (1.5 eq.) & $\mathbf{1 7}, 71$ \\
\hline 17 & 7 & 12 & TMSOTf (1.5 eq.) & 18,88 \\
\hline 18 & 7 & 13 & TMSOTf (1.5 eq.) & 19,75 \\
\hline 19 & 7 & 14 & TMSOTf (1.5 eq.) & $\mathbf{2 0}, 94$ \\
\hline 20 & 8 & 9 & TMSOTf (1.5 eq.) & 21,54 \\
\hline 21 & 8 & 10 & TMSOTf (1.5 eq.) & $\mathbf{2 2}, 77$ \\
\hline 22 & 8 & $11^{\mathrm{d}}$ & TMSOTf (1.5 eq.) & $\mathbf{2 3}, 76$ \\
\hline 23 & 8 & 12 & TMSOTf (1.5 eq.) & $\mathbf{2 4 , 6 6}$ \\
\hline 24 & 8 & 13 & TMSOTf (1.5 eq.) & $\mathbf{2 5}, 50$ \\
\hline 25 & 8 & 14 & TMSOTf (1.5 eq.) & $\mathbf{2 6}, 81$ \\
\hline
\end{tabular}

a) BSA (4 eq.) was used as silylating agent unless otherwise stated. b) the reaction mixture was heated for $12 \mathrm{~h}$ at $55{ }^{\circ} \mathrm{C}$ in $\mathrm{MeCN}$ unless otherwise stated c) the reaction was carried out in DCE. d) HMDS (1.8 eq.), saccharine (5 mol.\%) e) with BSTFA ( $N, O$-bis(trimethylsilyl)trifluoroacetamide). f) the reaction was carried out for $48 \mathrm{~h}$ at r.t.

With this donor in hand, we first performed the glycosylation of $\mathrm{N}^{4}$-Ac-cytosine 9, the nucleic base naturally present in the gougerotin. Reaction with $\mathrm{N}, \mathrm{O}$-bis(trimethylsilyl)acetamide (BSA) in $\mathrm{MeCN}$ gave the corresponding silylated cytosine, which was subsequently treated with $\mathbf{5}$ in the presence of 
trimethylsilyl triflate (TMSOTf, 1.5 eq.) for $12 \mathrm{~h}$ at $55{ }^{\circ} \mathrm{C} .{ }^{13}$ After workup and purification, the nucleoside $\mathbf{1 5}$ was isolated in $36 \%$ yield (Scheme 2, Table 1, entry 1) and as a single $\beta$ anomer due to the anchimeric assistance of the 2-OAc group. This was confirmed by the ${ }^{1} \mathrm{H}$ NMR spectrum showing a large coupling constant between protons $\mathrm{H}-1$ and $\mathrm{H}-2\left({ }^{3} J_{1,2}=9.5 \mathrm{~Hz}\right)$ indicating an axial orientation of both protons. The yield could be increased to $69 \%$ by using the Vorbrüggen method with $\mathrm{SnCl}_{4}$ (3 eq.) in $\mathrm{MeCN}_{\text {at }} 55^{\circ} \mathrm{C}$ for $12 \mathrm{~h}$ (Table 1, entry 2). ${ }^{14}$ The glycosylation of other pyrimidine bases was then tested and for each base, the reaction conditions had to be readjusted accordingly. The results are summarized in Table 1. Similar yields were obtained with thymine $\mathbf{1 0}$ (entry 3 ) and 5-F-uracil 11 (entry 4), which led respectively to the $\beta$-glycosylated adducts 16 and $\mathbf{1 7}$ in 74 and $71 \%$ yield respectively. Note that 5-F-uracil 11 was silylated in the presence of 1,1,1,3,3,3hexamethyldisilazane (HMDS) in combination with saccharin (5 mol\%) as catalyst. ${ }^{15}$ With 5-Me-N $\mathrm{N}^{4}$-Bz-cytosine 12 (entry 5) and 5-F-N ${ }^{4}-\mathrm{Bz}$-cytosine $\mathbf{1 3}$ (entry 6), which are rarely glycosylated with pyranosyl donors, moderate yields of 45 and $51 \%$ were achieved respectively for 18 and 19. A much lower yield of $25 \%$ was also obtained with silylated uracil 14 , which led to the corresponding $\beta$-nucleoside 20 (entry 7). This disappointing result led us to consider the use of other donors for these glycosylations. We started our investigations with the preparation of glycosyl ortho-hexynyl benzoate 6, readily accessible from $\mathbf{5}$ after selective deacetylation at the anomeric position and subsequent esterification of the corresponding hemiacetal (Scheme 1). Recently, these donors have been shown to be superior donors for the $N$-glycosylation of nucleobases using gold catalysis under very mild conditions. ${ }^{16}$ Donor 6 was then subjected to glycosylation with silylated pyrimidine bases under the catalysis of $\mathrm{Ph}_{3} \mathrm{PAuNTf}_{2}(10 \mathrm{~mol} \%)$ at room temperature in $\mathrm{MeCN}$. In all cases the corresponding nucleosides were isolated with an excellent $\beta$-selectivity but with variable yields depending on the acceptor. For example, a good $78 \%$ yield was obtained with uracil 14 (entry 13). Moderate results (30 to $49 \%$ ) were achieved with other bases (entries 8-11) and, with 5-F-N $\mathrm{N}^{4}-\mathrm{Bz}$ cytosine 13, the reaction led to a low conversion with the desired $\beta$-glycosylated adduct 19 been isolated in only $9 \%$ yield (entry 12 ). We then turned our attention to the use of sulfoxide donors ${ }^{17}$ that we recently exploited with success in problematic glycosylations ${ }^{18}$ and which have been very rarely used for the $N$-glycosylation with furanosyl or pyranosyl derivatives. ${ }^{19}$ Donor 7 was prepared from phenyl $\beta$-D-thiogalactoside $\mathbf{1 b}$, following the same strategy as for $\mathbf{5}$, i.e. 4,6-O-benzylidene acetal formation, $O$ $2 / O-3$ acetylation (to $\mathbf{2 b}$ ), reductive opening of the acetal $\left(\mathrm{Et}_{3} \mathrm{SiH} \text { with cat. } \mathrm{Cu}(\mathrm{OTf})_{2} \text { to } \mathbf{3 b}\right)^{20}$ and introduction of the azide at $\mathrm{C}-4$ through triflate displacement to afford $\mathbf{4 b}$ (Scheme 1). The obtained $\mathbf{4 b}$ was further treated by $\mathrm{NaI} / \mathrm{BF}_{3} \cdot \mathrm{OEt}_{2}$ in acetic anhydride leading to the acetolysis of the $6-O \mathrm{Bn}$ position. $^{21}$ Thioether oxidation was carried out under common conditions ( $m$-CPBA) smoothly giving sulfoxides 7 as a mixture of two diastereomers ( $\mathrm{dr}$ of 1:1). Donor 7 was then subjected to glycosylation after prior silylation of the pyrimidine bases with BSA in MeCN. In all cases, TMSOTf
(1.5 eq.) was used as promoter and after $12 \mathrm{~h}$ at $55^{\circ} \mathrm{C}$, we were pleased to obtain the corresponding $\beta$-nucleosides in good to excellent yields ranging from 71 to $95 \%$ (entries 14-19). We also prepared $6-\mathrm{OBn}$ sulfoxide derivatives 8 ( $\mathrm{dr}$ of $2: 3$ ) by direct oxidation of $\mathbf{4 b}$. $N$-glycosylation with this donor 8 efficiently led to $6-O \mathrm{Bn} \beta$-nucleosides in comparable yields (50-81\%, entries $20-25)$.

In order to carry out the peptide coupling and access analogues, we first examined azide reduction directly on compound $\mathbf{1 5}$. However, while using Staudinger conditions ${ }^{22}$ or different hydrogenation conditions to reduce the azide to amine, we
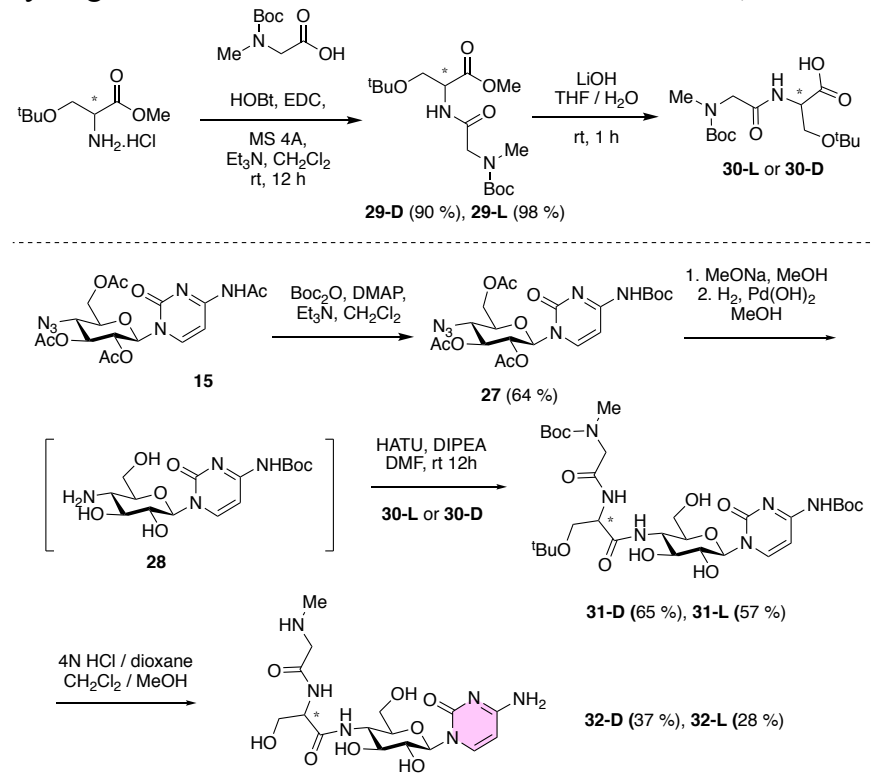

Scheme 3. Preparation of analogues 32-D and 32-L

obtained complex mixtures that probably result from deacetylation and acetate migration. To solve this problem, we decided to protect first the $\mathrm{N}^{4}$-cytosine with a tertbutylcarbamate group and remove all the acetyl groups before hydrogenation (Scheme 3). Therefore, compound 15 was treated with $\mathrm{Boc}_{2} \mathrm{O}$ in the presence of $\mathrm{NEt}_{3}$ and 4dimethylaminopyridine (DMAP) to provide the corresponding derivative 27 by concomitant deprotection of $\mathrm{N}^{4}$-Ac-cytosine. Zemplén deacetylation was carried out followed by hydrogenation with palladium hydroxide in methanol. This sequence led to the corresponding amine $\mathbf{2 8}$ that was used without purification in the following peptide coupling. The synthesis of the dipeptide fragment 30-D, naturally present in the gougerotin, started with the coupling of the methyl ester of D-O-tert-butyl-serine with Boc-sarcosine using hydroxybenzotriazole (HOBt) and 1-ethyl-3-(3dimethylaminopropyl)carbodiimide (EDC) in the presence of triethylamine in $\mathrm{CH}_{2} \mathrm{Cl}_{2}$. The obtained dipeptide 29-D was then saponified with lithium hydroxide to carboxylic acid 30-D. The same sequence was also performed with the methyl ester of L$O$-tert-butyl-serine providing the corresponding dipeptide fragment 30-L. The peptide coupling of amine $\mathbf{2 8}$ was then carried out with both dipeptides 30-D and 30-L using the coupling agent $\mathrm{HATU}^{23}$ in the presence of Hünig's base in DMF to furnish 31-D and 31-L in 65 and $57 \%$ yield 
respectively. Both compounds were then treated with $4 \mathrm{~N} \mathrm{HCl}$ in $\mathrm{MeOH} / \mathrm{CH}_{2} \mathrm{Cl}_{2}$ to remove the Boc and $t$-butyl groups allowing the preparation of analogues 32-D and 32-L. Due of the high polarity of these products and associated difficulties to their purification, these compounds were obtained in 37 and $28 \%$ yields respectively.

To access other compounds, the two uracil derivatives $\mathbf{1 6}$ and 17, were subjected to a similar reaction sequence, namely Zemplén deacetylation, hydrogenation followed by dipeptide coupling with carboxylic acid 30-D, affording the corresponding peptidonucleosides 33 and $\mathbf{3 4}$ (Scheme 4). Further deprotection with $\mathrm{HCl} 4 \mathrm{~N}$ allowed us to obtain analogues $\mathbf{3 5}$ and $\mathbf{3 6}$. For 34,

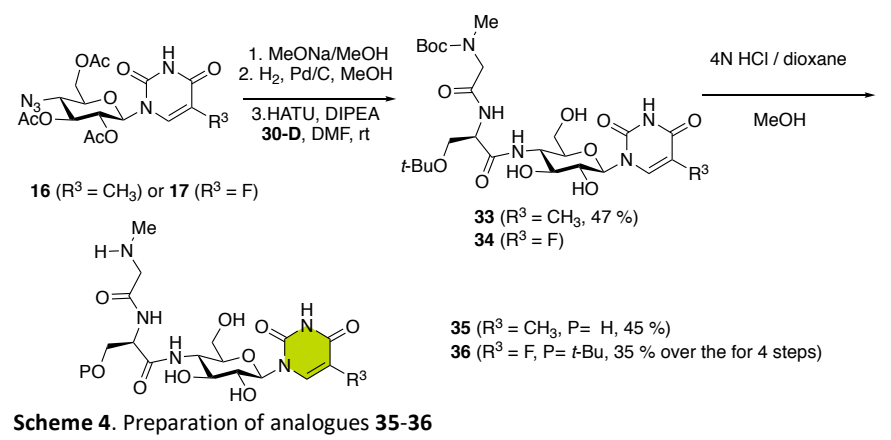

Scheme 4. Preparation of analogues 35-36
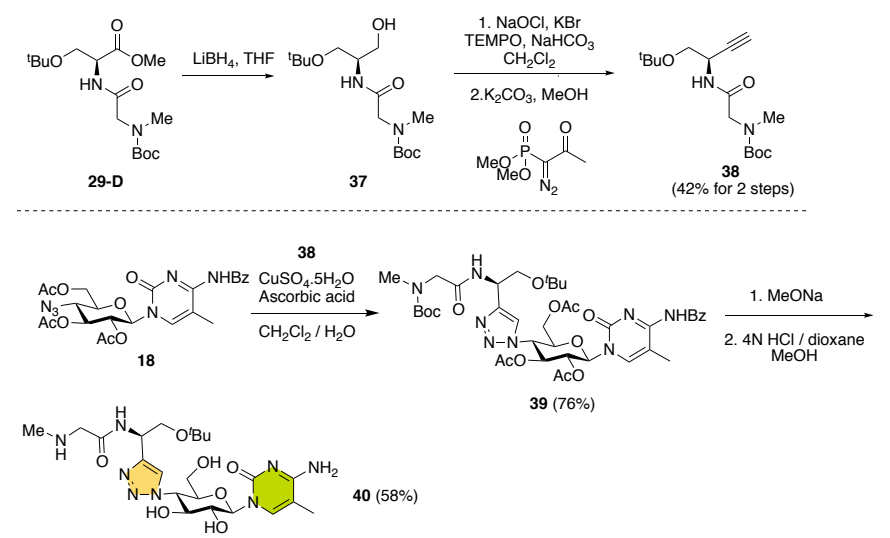

Scheme 5. Preparation of analogue $\mathbf{4 0}$

a partial deprotection was obtained leading to $\mathbf{3 6}$ as the major adduct still having the $t$-butyl group on the serine. Attempts to further deprotect compound $\mathbf{3 6}$ led to a very low yield of desired product due to degradation.

Taking advantage of the presence of the azide in position C-4 of pyranosyl compound 18, we also prepared compound $\mathbf{4 0}$ containing a triazole unit (Scheme 5). To this end we synthesized alkyne 38 from 29-D after its reduction to alcohol 37, oxidation to the aldehyde ${ }^{24}$ and treatment with dimethyl (1diazo-2-oxopropyl)phosphonate ${ }^{25}$ in the presence of potassium carbonate in $\mathrm{MeOH}$. The CuAAC reaction ${ }^{26}$ between alkyne 38 and azide $\mathbf{1 8}$ was carried out in a water/dichloromethane mixture with $\mathrm{CuSO}_{4} \cdot 5 \mathrm{H}_{2} \mathrm{O}$ and ascorbic acid to smoothly give the triazole derivative 39 in $76 \%$ yield. Final removal of the acyl groups with $\mathrm{MeONa}$ in methanol followed by treatment with $4 \mathrm{~N} \mathrm{HCl}$ at room temperature gave, as for 36, a partial deprotection leading to $\mathbf{4 0}$ having the $t$-butyl group on the serine as the major adduct in $58 \%$ yield.

The antifungal activities of some of the synthesized analogues including intermediates or not fully deprotected compounds were evaluated in preventive tests against a panel of different pathogens relevant to agriculture practices such as Podosphaera fuliginea (SPHRFU), Uromyces appendiculatus (UROMAP), Puccinia triticina (PUCCRT), Alternaria brassicae (ALTEBA), Botryotiniacinereal (BOTRCI), Zymoseptoria tritici (SEPPTR) (Table 2). Although some of the analogs were found to have good bioactivities, none of them showed superior activity to gougerotin itself. To be noted that only the activity against Podosphaera fuliginea was retained at $500 \mathrm{ppm}$ for certain analogues. These results show the importance of the carboxamide function and of the presence of the dipeptide chain in retaining all the activities.

Table 2. Antifungal activities of a selection of synthesized compounds

\begin{tabular}{|c|c|c|c|c|c|c|c|}
\hline Compound & {$[\mathrm{C}](\mathrm{ppm})$} & SPHRFU & UROMAP & PUCCRT & ALTEBA & BOTRCI & SEPPTR \\
\hline Gougerotin $^{\mathrm{a}}$ & 250 & $83 \%$ & $100 \%$ & $100 \%$ & - & - & $86 \%$ \\
\hline 22 & 500 & $70 \%$ & $0 \%$ & $0 \%$ & $0 \%$ & $0 \%$ & $20 \%$ \\
\hline 23 & 500 & $0 \%$ & $0 \%$ & $0 \%$ & $0 \%$ & $0 \%$ & $0 \%$ \\
\hline 24 & 500 & $83 \%$ & $0 \%$ & $0 \%$ & $0 \%$ & $0 \%$ & $0 \%$ \\
\hline 26 & 500 & $83 \%$ & $0 \%$ & $0 \%$ & $0 \%$ & $0 \%$ & $0 \%$ \\
\hline 32-L & 500 & $90 \%$ & $11 \%$ & $67 \%$ & $25 \%$ & $45 \%$ & $79 \%$ \\
\hline 32-D & 500 & $75 \%$ & $86 \%$ & $0 \%$ & $0 \%$ & $0 \%$ & $43 \%$ \\
\hline 33 & 500 & $0 \%$ & $0 \%$ & $0 \%$ & $0 \%$ & $0 \%$ & $0 \%$ \\
\hline 34 & 500 & $44 \%$ & $0 \%$ & $0 \%$ & $0 \%$ & $0 \%$ & $0 \%$ \\
\hline 36 & 500 & $80 \%$ & $0 \%$ & $0 \%$ & $0 \%$ & $0 \%$ & $20 \%$ \\
\hline
\end{tabular}

a) Gougerotin $80 \%$ from fermentation broth 


\section{Conclusions}

In this article, we have successfully prepared a series of peptidonucleosides, analogues of gougerotin. The main modifications relate to the replacement of the natural nucleic base by other pyrimidine bases and the replacement of the carboxamide function at C5 by an hydroxymethyl group. For the glycosylation stage, a methodological study involving different anomeric leaving groups (acetate, phenylsulfoxide and ortho-hexynylbenzoate) was carried out. Using six different pyrimidines, the sulfoxide donor in combination with TMSOTf as a promoter most generally led to the best yields. Unfortunately, none of the prepared compounds showed superior antifungal activity to gougerotin itself. In order to fully explore and optimize the structural features of this family leading to new compounds towards the potential development of a new class of therapeutically useful antifungal agents, an investigation of other gougerotin analogues is still ongoing.

\section{Experimental}

\section{General remarks}

All non-aqueous reactions were run under an inert atmosphere (argon), by using standard techniques for manipulating airsensitive compounds and the glassware was stored in the oven prior to use. All reagents and solvents were commercially available and were used without further purification. Molecular sieves $4 \AA$ were used as a powder and were activated overnight at $250{ }^{\circ} \mathrm{C}$ and under reduced pressure, in a Kugelrohr apparatus or with a micro-wave for 45 seconds. Reactions were monitored with analytical Merck TLC silica gel 60 F254 plates and visualized under UV (254 nm) and stained with $\mathrm{KMNO}_{4}$ or vanillin. Column chromatography was done with Merck Geduran silical gel Si $60(40-63 \mu \mathrm{m})$ and Redisep Rf columns (silica gel Si $60,40-63 \mu \mathrm{m}$ ) on an Interchim puriFlash $^{\circledR}$ apparatus and on a Teledyne Isco combiflash Rf. Preparative thin-layer chromatography was performed on silica gel 60 F254 $0.5 \mathrm{~mm} 20 \times 20 \mathrm{~cm}$ plates and visualised under UV $(254 \mathrm{~nm})$. Deuterated chloroform used for NMR analyses was generally neutralized by addition of anhydrous and granular $\mathrm{K}_{2} \mathrm{CO}_{3}$. NMR spectra were recorded with AM 300, AVANCE 300 and AVANCE 500 Brüker spectrometers. Chemical shifts are given in parts per million, referenced to the solvent peak of $\mathrm{CDCl}_{3}$, defined at $77.2 \mathrm{ppm}\left({ }^{13} \mathrm{C} \mathrm{NMR}\right)$ and $7.26 \mathrm{ppm}\left({ }^{1} \mathrm{H} \mathrm{NMR}\right)$ or to the solvent peak of $\mathrm{CD}_{3} \mathrm{OD}$, defined at $49.9 \mathrm{ppm}\left({ }^{13} \mathrm{C} \mathrm{NMR}\right)$ and $3.34 \mathrm{ppm}\left({ }^{1} \mathrm{H} \mathrm{NMR}\right)$ or to the solvent peak of $\mathrm{D}_{2} \mathrm{O}$, defined at $4.79 \mathrm{ppm}\left({ }^{1} \mathrm{H} \mathrm{NMR}\right)$ or to the solvent peak of DMSO- $\mathrm{d}_{6}$, defined at $39.5 \mathrm{ppm}\left({ }^{13} \mathrm{C}\right.$ NMR $)$ and $2.50 \mathrm{ppm}\left({ }^{1} \mathrm{H} \mathrm{NMR}\right)$. Data are reported as follow: chemical shifts, multiplicity $(\mathrm{s}=$ singlet, $\mathrm{d}=$ doublet, $\mathrm{t}=$ triplet, $\mathrm{q}=$ quadruplet, $\mathrm{m}=$ multiplet, $\mathrm{bs}=$ broad singlet), coupling constant (in $\mathrm{Hz}$ ) and integration. IR spectra were recorded on a Perkin-Elmer Spectrum BX instrument with an FT-IR system. Optical rotation were measured on an Anton Paar MCP300 polarimeter using a cell of 1-dm-length path. Mass spectra were recorded with Waters Micromass LCT Premier mass spectrometer.

\section{General Procedure for the glycosylation of sulfoxide donors.}

To a stirred solution of the nitrogen base (1.6 eq.) in dry MeCN $\left(2 / 3 \mathrm{~V}_{\text {tot }}\right)$ under argon atmosphere was added BSA (4 eq.). The resulting mixture was heated at $60{ }^{\circ} \mathrm{C}$ for $1 \mathrm{~h}$ and then cooled to room temperature. The donor ( 1 eq.) is stirred with $4 \AA$ molecular sieves in dry MeCN (1/3 Vtot) under argon for $1 \mathrm{~h}$. The solution of the nitrogen base was added to the donor and then TMSOTf (1.5 eq.). The resulting mixture was heated at 55 ${ }^{\circ} \mathrm{C}$ overnight and then quenched with aqueous $\mathrm{NaHCO}_{3}$. The reaction mixture was filtered and the aqueous phase was extracted with EtOAc (5x). The organic layers were combined, washed with $\mathrm{NaCl}$, dried over $\mathrm{Na}_{2} \mathrm{SO}_{4}$, filtered and concentrated under vacuum. The residue was purified by flash chromatography on silica gel to afford the clean product.

\section{2,3,6-Tri- $O$-acetyl-4-azido-1- $N$-( $N$-acetyl-cytosine)- $\beta$-D-}

glucopyranoside 15. The General Procedure was followed using 7 (300 mg, $0.68 \mathrm{mmol}), 9$ (184 mg, $1.09 \mathrm{mmol})$, BSA (0.67 mL, $2.72 \mathrm{mmol})$, TMSOTf $(0.18 \mathrm{~mL}, 1.02 \mathrm{mmol}), 4 \AA$ molecular sieves $(200 \mathrm{mg})$ in dry $\mathrm{MeCN}(13.6 \mathrm{~mL})$. The residue was purified by flash chromatography on silica gel (EtOAc) to afford product $\mathbf{1 5}$ (304 $\mathrm{mg}, 0.65 \mathrm{mmol}, 95 \%)$ as a colorless oil. $[\alpha]_{\mathrm{D}}{ }^{25}+56.6\left(c=1.0, \mathrm{CHCl}_{3}\right) ;{ }^{1} \mathrm{H}$ NMR $(300$ $\left.\mathrm{MHz}, \mathrm{CD}_{3} \mathrm{OD}\right) \delta 8.14\left(\mathrm{~d}, 1 \mathrm{H}, J_{H A r, H A r}=7.5 \mathrm{~Hz}, H_{\mathrm{Ar}}\right), 7.49(\mathrm{~d}$, $\left.1 \mathrm{H}, J_{H A r, H A r}=7.5 \mathrm{~Hz}, H_{\mathrm{Ar}}\right), 6.12\left(\mathrm{~d}, 1 \mathrm{H}, J_{1,2}=9.0 \mathrm{~Hz}, H 1\right), 5.54$ $\left(\mathrm{t}, 1 \mathrm{H}, J_{3,2}=J_{3,4}=9.5 \mathrm{~Hz}, H 3\right), 5.32\left(\mathrm{t}, 1 \mathrm{H}, J_{2,3}=J_{2,1}=9.5 \mathrm{~Hz}\right.$, $H 2), 4.47\left(\mathrm{dd}, 1 \mathrm{H}, J_{6,6^{\prime}}=13.0 \mathrm{~Hz}\right.$ and $\left.J_{6,5}=1.0 \mathrm{~Hz}, H 6\right), 4.31$ $\left(\mathrm{dd}, 1 \mathrm{H}, J_{6^{\prime}, 6}=13.0 \mathrm{~Hz}\right.$ and $\left.J_{6^{\prime}, 5}=4.5 \mathrm{~Hz}, H 6^{\prime}\right), 4.00-3.93(\mathrm{~m}$, $2 \mathrm{H}, H 4, H 5), 2.21\left(\mathrm{~s}, 3 \mathrm{H}, \mathrm{NHCOCH}_{3}\right), 2.14\left(\mathrm{~s}, 3 \mathrm{H}, \mathrm{OCOCH}_{3}\right)$, $2.12\left(\mathrm{~s}, 3 \mathrm{H}, \mathrm{OCOCH}_{3}\right), 1.94\left(\mathrm{~s}, 3 \mathrm{H}, \mathrm{OCOCH}_{3}\right) ;{ }^{13} \mathrm{C}$ NMR $(75$ $\left.\mathrm{MHz}, \mathrm{CD}_{3} \mathrm{OD}\right) \delta 173.9(C=\mathrm{O}), 173.1(C=\mathrm{O}), 172.0(C=\mathrm{O})$, $172.0(C=\mathrm{O}), 165.5\left(C \mathrm{q}_{\mathrm{Ar}}\right), 158.6\left(\mathrm{Cq}_{\mathrm{Ar}}\right), 147.5\left(\mathrm{CH}_{\mathrm{Ar}}\right), 99.8$ $\left(\mathrm{CH}_{\mathrm{Ar}}\right), 83.6(C 1), 77.1(C 4), 75.4(C 3), 73.2$ (C2), 64.8 (C6), $61.9(C 5), 25.4\left(\mathrm{COCH}_{3}\right), 21.4\left(\mathrm{COCH}_{3}\right), 21.1\left(\mathrm{COCH}_{3}\right)$; IR $v$ (film, cm $\left.{ }^{-1}\right) 3239(=\mathrm{C}-\mathrm{H}), 2112\left(\mathrm{~N}_{3}\right), 1747(\mathrm{C}=\mathrm{O}), 1663(\mathrm{NH}-$ $\mathrm{C}=\mathrm{O}) ; \quad$ ESIHRMS $m / z=467.1486 \quad[\mathrm{M}+\mathrm{H}]^{+} . \quad \mathrm{C}_{18} \mathrm{H}_{23} \mathrm{~N}_{6} \mathrm{O} 9$ requires 467.1527 . 


\section{2,3,6-Tri-O-acetyl-4-azido-1- $N$-( $N$-tert-butyloxycarbonyl--} cytosine)- $\boldsymbol{\beta}$-D-glucopyranoside 27 . To a stirred solution of $\mathbf{1 5}$ (40 mg, $0.09 \mathrm{mmol})$ in $\mathrm{CH}_{2} \mathrm{Cl}_{2}(1 \mathrm{~mL})$ was added di-tert-butyldicarbonate ( $40 \mu \mathrm{L}, 0.17 \mathrm{mmol}, 2$ eq.), triethylamine $(12 \mu \mathrm{L}$, $0.09 \mathrm{mmol}, 1 \mathrm{eq}$.) and 4-dimethylaminopyridine (10.5 mg, 0.09 mmol, 1 eq.). The resulting mixture was stirred at room temperature for $4 \mathrm{~h}$ and then concentrated under reduced pressure. The residue was purified by flash chromatography on silica gel $\left(\mathrm{CH}_{2} \mathrm{Cl}_{2} / \mathrm{MeOH} 99: 1\right.$ to $\left.98: 2\right)$ to afford product 27 (29 $\mathrm{mg}, 0.06 \mathrm{mmol}, 64 \%)$ as a yellow powder. $[\alpha]_{\mathrm{D}}{ }^{25}+41.7(c=$ 1.2, $\left.\mathrm{CHCl}_{3}\right) ;{ }^{1} \mathrm{H}$ NMR $\left(300 \mathrm{MHz}, \mathrm{CDCl}_{3}\right) \delta 7.62\left(\mathrm{~d}, 1 \mathrm{H}, J_{H A r, H A r}\right.$ $\left.=7.5 \mathrm{~Hz}, H_{\mathrm{Ar}}\right), 7.30\left(\mathrm{~d}, 1 \mathrm{H}, J_{H A r, H A r}=7.5 \mathrm{~Hz}, H_{\mathrm{Ar}}\right), 6.05(\mathrm{~d}, 1 \mathrm{H}$, $\left.J_{1,2}=9.5 \mathrm{~Hz}, H 1\right), 5.40\left(\mathrm{t}, 1 \mathrm{H}, J_{2,1}=J_{2,3}=9.5 \mathrm{~Hz}, H 2\right), 5.07(\mathrm{t}$, $\left.1 \mathrm{H}, J_{3,2}=J_{3,4}=9.5 \mathrm{~Hz}, H 3\right), 4.39\left(\mathrm{~d}, 1 \mathrm{H}, J_{6,6^{\prime}}=12.5 \mathrm{~Hz}, H 6\right)$, $4.27\left(\mathrm{dd}, 1 \mathrm{H}, J_{6^{\prime}, 6}=12.5 \mathrm{~Hz}, J_{6^{\prime}, 5}=4.0 \mathrm{~Hz}, H 6^{\prime}\right), 3.76-3.67(\mathrm{~m}$, $2 \mathrm{H}, \mathrm{H} 4, \mathrm{H5}), 2.11\left(\mathrm{~s}, 6 \mathrm{H}, \mathrm{OCOCH}_{3}\right), 1.97\left(\mathrm{~s}, 3 \mathrm{H}, \mathrm{OCOCH}_{3}\right)$, $1.51\left(\mathrm{~s}, 9 \mathrm{H}, \mathrm{OC}\left(\mathrm{CH}_{3}\right)_{3}\right) ;{ }^{13} \mathrm{C} \mathrm{NMR}\left(75 \mathrm{MHz}, \mathrm{CDCl}_{3}\right) \delta 170.5$ $(C=\mathrm{O}), 170.2(C=\mathrm{O}), 169.5(C=\mathrm{O}), 143.8\left(C \mathrm{H}_{\mathrm{Ar}}\right), 96.3\left(C \mathrm{H}_{\mathrm{Ar}}\right)$, 83.7 (Cq), $81.3(C 1), 75.5(C 4), 73.5(C 3), 70.7(C 2), 62.7$ (C6), $60.2(\mathrm{C5}), 28.2\left(\mathrm{C}\left(\mathrm{CH}_{3}\right)_{3}\right), 20.9\left(\mathrm{COCH}_{3}\right), 20.8\left(\mathrm{COCH}_{3}\right)$, $20.6\left(\mathrm{COCH}_{3}\right)$; IR $v$ (film, cm $\left.{ }^{-1}\right) 2987(\mathrm{C}-\mathrm{H}), 2109\left(\mathrm{~N}_{3}\right), 1751$ $(\mathrm{C}=\mathrm{O}), 1731 \quad(\mathrm{C}=\mathrm{O}), 1667 \quad(\mathrm{NH}-\mathrm{C}=\mathrm{O}), 1626 \quad(\mathrm{NH}-\mathrm{C}=\mathrm{O})$; ESIHRMS $m / z=525.1945[\mathrm{M}+\mathrm{H}]^{+} . \mathrm{C}_{21} \mathrm{H}_{29} \mathrm{~N}_{6} \mathrm{O}_{10}$ requires 525.1953 .

Methyl Boc-sarcosinyl-O-tert-butyl-D-serinate 29-D. To a stirred solution of $O$-tert-butyl-D-serine methyl ester $(250 \mathrm{mg}$, $1.18 \mathrm{mmol}, 1$ eq.) and Boc-sarcosine (290 mg, $1.54 \mathrm{mmol}, 1.3$ eq.) in dry $\mathrm{CH}_{2} \mathrm{Cl}_{2}(9.8 \mathrm{~mL})$ were added $4 \AA$ molecular sieves (400 mg), hydroxybenzotriazole ( $239 \mathrm{mg}, 1.77 \mathrm{mmol}, 1.5 \mathrm{eq}$. and 1-ethyl-3-(3-dimethylaminopropyl)carbodiimide (452 $\mathrm{mg}$, $2.36 \mathrm{mmol}, 2$ eq.). The resulting mixture was cooled to $0{ }^{\circ} \mathrm{C}$ and $\mathrm{Et}_{3} \mathrm{~N}$ (0.49 mL, $3.54 \mathrm{mmol}, 3$ eq.) was added. After being stirred overnight at room temperature, the mixture was diluted with aqueous saturated $\mathrm{NaHCO}_{3}(8 \mathrm{~mL})$. The aqueous phase was then extracted with EtOAc $(3 \times 10 \mathrm{~mL})$. The organic layers were combined, dried over $\mathrm{Na}_{2} \mathrm{SO}_{4}$, filtered and concentrated under vacuum. The residue was purified by flash chromatography on silica gel (Heptane/EtOAc 80:20 to 60:40) to afford product 29-D (367 g, 90\%) as a colorless oil. $[\alpha]_{\mathrm{D}}{ }^{25}-$ $26.4\left(c=1.0, \mathrm{CHCl}_{3}\right) ;{ }^{1} \mathrm{H} \mathrm{NMR}\left(300 \mathrm{MHz}, \mathrm{CDCl}_{3}\right) \delta 4.69(\mathrm{~m}$, $1 \mathrm{H}, H 2), 4.17-3.81(\mathrm{~m}, 2 \mathrm{H}, H 3), 3.80\left(\mathrm{dd}, 1 \mathrm{H}, J_{l, l},=9.0 \mathrm{~Hz}\right.$, $\left.J_{l^{\prime}, 1}=3.0 \mathrm{~Hz}, H 1\right), 3.72\left(\mathrm{~s}, 3 \mathrm{H}, \mathrm{OCH}_{3}\right), 3.53\left(\mathrm{dd}, 1 \mathrm{H}, J_{l, l}=9.0\right.$ $\left.\mathrm{Hz}, J_{l^{\prime}, 1}=3.0 \mathrm{~Hz}, H 1\right), 2.93\left(\mathrm{~s}, 3 \mathrm{H}, \mathrm{NCH}_{3}\right), 1.46(\mathrm{~s}, 9 \mathrm{H}$, $\left.\mathrm{CO}_{2} \mathrm{C}\left(\mathrm{CH}_{3}\right)_{3}\right), 1.10\left(\mathrm{~s}, 9 \mathrm{H}, \mathrm{OC}\left(\mathrm{CH}_{3}\right)_{3}\right) ;{ }^{13} \mathrm{C} \mathrm{NMR}(75 \mathrm{MHz}$, $\left.\mathrm{CDCl}_{3}\right) \delta 62.1(\mathrm{Cl}), 53.4(\mathrm{C3}), 52.8(\mathrm{C2}), 52.6\left(\mathrm{OCH}_{3}\right), 35.7$ $\left(\mathrm{NCH}_{3}\right), 28.5\left(\mathrm{CO}_{2} \mathrm{C}\left(\mathrm{CH}_{3}\right)_{3}\right), 27.5\left(\mathrm{OC}\left(\mathrm{CH}_{3}\right)_{3}\right) ; \mathrm{IR} v$ (film, $\mathrm{cm}^{-}$ 1) $3314(\mathrm{~N}-\mathrm{H}), 2975\left(\mathrm{CH}_{3}\right), 2935\left(\mathrm{CH}_{2}\right), 1751(\mathrm{C}=\mathrm{O}), 1684$ $(\mathrm{NH}-\mathrm{C}=\mathrm{O})$; ESIHRMS $m / z=347.2182[\mathrm{M}+\mathrm{H}]^{+} . \mathrm{C}_{16} \mathrm{H}_{31} \mathrm{~N}_{2} \mathrm{O}_{6}$ requires 347.2191 .

Boc-sarcosinyl-O-tert-butyl-D-serine 30-D. To a stirred solution of 29-D (367 mg, $1.06 \mathrm{mmol}, 1$ eq.) in $\mathrm{THF} / \mathrm{H}_{2} \mathrm{O}$

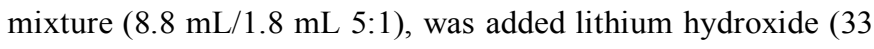
$\mathrm{mg}, 1.38 \mathrm{mmol}, 1.3 \mathrm{eq}$.). The resulting mixture was stirred for 1 $\mathrm{h}$ at room temperature and then concentrated under vacuum until THF was evaporated. $\mathrm{HCl} 1 \mathrm{~N}$ was then added until the
$\mathrm{pH}$ 2. The aqueous layer was extracted with EtOAc $(3 \times 10$ $\mathrm{mL}$ ). The organic layers were combined, dried over $\mathrm{Na}_{2} \mathrm{SO}_{4}$ and concentrated under vacuum to afford the clean product 30D (351 mg, $1.06 \mathrm{mmol}$, quantitative). The product is used without further purification. [ $\alpha]_{\mathrm{D}}{ }^{25}-32.8\left(c=1.0, \mathrm{CHCl}_{3}\right) ;{ }^{1} \mathrm{H}$ NMR $\left(300 \mathrm{MHz}, \mathrm{CDCl}_{3}\right) \delta 6.90\left(\mathrm{~d}, 1 \mathrm{H}, J_{N H, H 2}=8.0 \mathrm{~Hz}, N \mathrm{H}\right)$, $4.68(\mathrm{~m}, 1 \mathrm{H}, H 2), 4.07-3.64\left(\mathrm{~m}, 2 \mathrm{H}, H 3, H 3{ }^{\prime}\right), 3.85(\mathrm{dd}, 1 \mathrm{H}$, $\left.J_{l, I^{\prime}}=9.0 \mathrm{~Hz}, J_{l, 2}=3.0 \mathrm{~Hz}, H 1\right), 3.55\left(\mathrm{dd}, 1 \mathrm{H}, J_{l, I^{\prime}}=9.0 \mathrm{~Hz}\right.$, $\left.J_{l^{\prime}, 2}=4.0 \mathrm{~Hz}, H 1^{\prime}\right), 2.92\left(\mathrm{~s}, 3 \mathrm{H}, \mathrm{NCH}_{3}\right), 1.44(\mathrm{~s}, 9 \mathrm{H}$, $\left.\mathrm{CO}_{2} \mathrm{C}\left(\mathrm{CH}_{3}\right)_{3}\right), 1.12\left(\mathrm{~s}, 9 \mathrm{H}, \mathrm{OC}\left(\mathrm{CH}_{3}\right)_{3}\right) ;{ }^{13} \mathrm{C} \mathrm{NMR}(75 \mathrm{MHz}$, $\left.\mathrm{CDCl}_{3}\right) \delta 173.7(C=\mathrm{O}), 169.9(C=\mathrm{O}), 81.2\left(\mathrm{Cq}_{\mathrm{CO} 2 C(\mathrm{CH} 3) 3}\right), 74.1$ (CqoC(CH3)3), $61.7(C 1), 53.3(C 3), 52.7(C 2), 35.8\left(\mathrm{NCH}_{3}\right), 28.5$ $\left(\mathrm{CO}_{2} \mathrm{C}\left(\mathrm{CH}_{3}\right)_{3}\right), 27.5\left(\mathrm{OC}\left(\mathrm{CH}_{3}\right)_{3}\right)$; IR v (film, $\left.\mathrm{cm}^{-1}\right) 3320(\mathrm{O}-\mathrm{H})$, $2975\left(\mathrm{CH}_{3}\right), 2935\left(\mathrm{CH}_{2}\right), 1739(\mathrm{C}=\mathrm{O}), 1670 \quad(\mathrm{NH}-\mathrm{C}=\mathrm{O})$; ESIHRMS $m / z=355.1842[\mathrm{M}+\mathrm{Na}]^{+} . \mathrm{C}_{15} \mathrm{H}_{28} \mathrm{~N}_{2} \mathrm{O}_{6} \mathrm{Na}$ requires 355.1845 .

Peptidonucleoside 31-D. The solution 1 was prepared with $\mathrm{Na}$ $(10 \mathrm{mg})$ in dry $\mathrm{MeOH}(2 \mathrm{~mL}, \mathrm{C}=0.22 \mathrm{M})$. To a stirred solution of the protected nucleoside $27(147 \mathrm{mg}, 0.28 \mathrm{mmol})$ in dry $\mathrm{MeOH}(5 \mathrm{~mL})$ was added the solution $1(0.26 \mathrm{~mL}, 20 \mathrm{~mol} \%)$. The resulting mixture was stirred at room temperature for $1 \mathrm{~h}$ and then neutralized with Dowex ${ }^{\circledR} \mathrm{H}^{+}$, filtered on celite and concentrated under reduce pressure to afford clean product without further purification. The obtained product $(105 \mathrm{mg})$ was then hydrogenated at atmospheric pressure in the presence of $\mathrm{Pd}(\mathrm{OH})_{2}(40 \% \mathrm{w} / \mathrm{w}, 42 \mathrm{mg})$ in $\mathrm{MeOH}(2.6 \mathrm{~mL})$ for $12 \mathrm{~h}$. The resulting mixture was then filtered on celite ${ }^{\circledR}$ and concentrated under reduced pressure to afford the clean corresponding amine (94 mg). To a stirred solution of the latter in DMF (4 mL) was added the dipeptide (109 $\mathrm{mg}, 0.33 \mathrm{mmol}, 1.3$ eq.) and DIPEA (0.17 mL, $1.01 \mathrm{mmol}, 4$ eq.). After $1 \mathrm{~min}$, HATU (144 mg, 0.32 mmol, 1.5 eq.) was added and the resulting mixture was stirred at room temperature for $18 \mathrm{~h}$. Solvent was removed and the crude product was purified by flash chromatography on silica gel (EtOAc/EtOH 99:1 to 92:8) to afford product 31-D (113 mg, $0.16 \mathrm{mmol}, 65 \%)$ as a yellow powder; $[\alpha]_{\mathrm{D}}{ }^{25}+14.6(c=1.1$, $\mathrm{MeOH}) .{ }^{1} \mathrm{H}$ NMR $\left(500 \mathrm{MHz}, \mathrm{CD}_{3} \mathrm{OD}\right)^{27} \delta 8.11\left(\mathrm{~d}, 1 \mathrm{H}, J_{H A r, H A r}\right.$ $\left.=7.5 \mathrm{~Hz}, H_{\mathrm{Ar}}\right), 7.33-7.26\left(\mathrm{~m}, 1 \mathrm{H}, H_{\mathrm{Ar}}\right), 5.77\left(\mathrm{~d}, 1 \mathrm{H}, J_{l, 2}=9.0\right.$ $\mathrm{Hz}, H 1), 4.60-4.49$ (m, 1H, H7), 4.10-3.53 (m, 10H, H2, H3, $H 4, H 5, H 6, H 8, H 9), 3.03-2.83\left(\mathrm{~m}, 3 \mathrm{H}, \mathrm{NCH}_{3}\right), 1.56(\mathrm{~s}, 9 \mathrm{H}$, $\left.\mathrm{CO}_{2} \mathrm{C}\left(\mathrm{CH}_{3}\right)_{3}\right), 1.50-1.41\left(\mathrm{~m}, 9 \mathrm{H}, \mathrm{OC}\left(\mathrm{CH}_{3}\right)_{3}\right), 1.20(\mathrm{~s}, 9 \mathrm{H}$, $\left.\mathrm{CO}_{2} \mathrm{C}\left(\mathrm{CH}_{3}\right)_{3}\right) ;{ }^{13} \mathrm{C} \mathrm{NMR}\left(75 \mathrm{MHz}, \mathrm{CD}_{3} \mathrm{OD}\right){ }^{28} \delta 172.1(\mathrm{C}=\mathrm{O})$, $163.7(C \mathrm{q}), 157.0(\mathrm{Cq}), 156.9(\mathrm{Cq}), 151.9(C=\mathrm{O}), 144.9(\mathrm{CH}$,

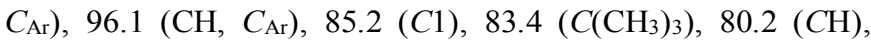
$75.8(\mathrm{CH}), 74.4\left(\mathrm{CH}_{2}\right), 73.9\left(\mathrm{C}\left(\mathrm{CH}_{3}\right)_{3}\right), 73.8\left(\mathrm{C}_{\left.\left(\mathrm{CH}_{3}\right)_{3}\right),} 71.6\right.$ $\left(\mathrm{CH}_{2}\right), 62.8\left(\mathrm{CH}_{2}\right), 56.1(\mathrm{C7}), 53.4(\mathrm{CH}), 53.1\left(\mathrm{CH}_{2}\right), 36.8$

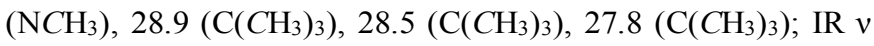
(film, cm $\left.{ }^{-1}\right) 3264(\mathrm{~N}-\mathrm{H}), 2976(\mathrm{CH}), 2926(\mathrm{CH}), 1758(\mathrm{C}=\mathrm{O})$, $1656(\mathrm{NH}-\mathrm{C}=\mathrm{O}) ; \quad$ ESIHRMS $m / z=687.3566[\mathrm{M}+\mathrm{H}]^{+}$. $\mathrm{C}_{30} \mathrm{H}_{51} \mathrm{~N}_{6} \mathrm{O}_{12}$ requires 687.3565 .

Peptidonucleoside 32-D. To a stirred solution of 31-D (90 mg, $0.131 \mathrm{mmol}, 1$ eq.) in $\mathrm{CH}_{2} \mathrm{Cl}_{2} / \mathrm{MeOH}(2: 1 \mathrm{v} / \mathrm{v}, 1.3 \mathrm{~mL})$ was added a solution of $4 \mathrm{M} \mathrm{HCl}$ in dioxane $(0.23 \mathrm{~mL}, 0.92 \mathrm{mmol}, 7$ eq.). The resulting mixture was stirred at room temperature for 2 days and then diluted with $\mathrm{H}_{2} \mathrm{O}$ and then neutralized with 
DOWEX ${ }^{\circledR}$ MONOSPHERE ${ }^{\circledR} 550 \mathrm{~A}(\mathrm{OH})$ anion exchange resin. The mixture was filtered on celite and then concentrated under vaccum. The crude product was purified by preparative TLC $\left(\mathrm{H}_{2} \mathrm{O} / \mathrm{EtOH} /\right.$ EtOAc 4:4:2, pH 9) to afford 32-D as a white powder (21 mg, $0.05 \mathrm{mmol}, 37 \%)$. [ $\alpha]_{\mathrm{D}^{25}}-31.3\left(c=1.1, \mathrm{H}_{2} \mathrm{O}\right)$; ${ }^{1} \mathrm{H}$ NMR $\left(300 \mathrm{MHz}, \mathrm{D}_{2} \mathrm{O}\right) \delta 7.73\left(\mathrm{~d}, 1 \mathrm{H}, J_{H A r, H A r}=7.5 \mathrm{~Hz}, H_{\mathrm{Ar}}\right)$, $6.07\left(\mathrm{bs}, 1 \mathrm{H}, H_{\mathrm{Ar}}\right), 5.64\left(\mathrm{~d}, 1 \mathrm{H}, J_{l, 2}=9.5 \mathrm{~Hz}, H 1\right), 4.45(\mathrm{t}, 1 \mathrm{H}$, $\left.J_{7,8}=J_{7,8^{\prime}}=5.5 \mathrm{~Hz}, H 7\right), 3.94(\mathrm{~s}, 2 \mathrm{H}, H 9), 3.91-3.80(\mathrm{~m}, 1 \mathrm{H}$, $H 4), 3.86\left(\mathrm{~d}, 2 \mathrm{H}, J_{8,7}=5.5 \mathrm{~Hz}, H 8\right), 3.80-3.71(\mathrm{~m}, 3 \mathrm{H}, H 2, H 3$, H5), $3.68\left(\mathrm{dd}, 1 \mathrm{H}, J_{6,6^{\prime}}=12.5 \mathrm{~Hz}, J_{6,5}=1.5 \mathrm{~Hz}, H 6\right), 3.57$ (dd, $\left.1 \mathrm{H}, J_{6,6}=12.5 \mathrm{~Hz}, J_{6,5}=5.5 \mathrm{~Hz}, H 6^{\prime}\right), 2.74\left(\mathrm{~s}, 3 \mathrm{H}, \mathrm{NCH}_{3}\right) ;{ }^{13} \mathrm{C}$ NMR $\left(75 \mathrm{MHz}, \mathrm{D}_{2} \mathrm{O}\right) \delta 172.0(C=\mathrm{O}), 166.7(C=\mathrm{O}), 166.0$ $(C=\mathrm{O}), 157.9\left(C \mathrm{q}_{\mathrm{Ar}}\right), 141.7\left(C \mathrm{H}_{\mathrm{Ar}}\right), 97.0\left(C \mathrm{H}_{\mathrm{Ar}}\right), 83.3(C 1)$, 77.5 (C5), 73.7 (C3), 71.7 (C2), 61.0 (C8), 60.6 (C6), 55.9 (C7), 51.3 (C4), 49.4 (C9), $32.8\left(\mathrm{NCH}_{3}\right)$; IR v (film, cm $\left.{ }^{-1}\right) 3310$ $(\mathrm{O}-\mathrm{H}), 3282(\mathrm{~N}-\mathrm{H}), 2976\left(\mathrm{CH}_{3}\right), 2933\left(\mathrm{CH}_{2}\right), 1744(\mathrm{C}=\mathrm{O})$, $1653(\mathrm{NH}-\mathrm{C}=\mathrm{O}) ; \quad$ ESIHRMS $m / z=431.3424[\mathrm{M}+\mathrm{H}]^{+}$. $\mathrm{C}_{16} \mathrm{H}_{28} \mathrm{~N}_{6} \mathrm{O}_{8}$ requires 431.1890 .

\section{Conflicts of interest}

There are no conflicts to declare

\section{Acknowledgements}

We gratefully acknowledge financial supports from CNRS and from Bayer CropScience (PhD thesis of MB).

\section{Notes and references}

1 R. P. Oliver and H. G. Hewitt, Fungicides in crop protection, Cabi, 2014.

2 P. Jeschke, Pest Manag Sci, 2016, 72, 210.

3 M. C. Fisher, N. J. Hawkins, D. Sanglard and S. J. Gurr, Science, 2018, 360, 739.

4 T. Kanzaki, E. Higashide, H. Yamamoto, H. Shibata, K. Nakazma, H. Iwasaki, T. Takewaka, A. Miyake, J. Antibiot. (Tokyo), 1962, 15, 93.

5 W. Andersch, R. N. Royalty, F. D. Smith, B. Springer and W. Thielert, Compositions comprising gougerotin and a biological control agent, US20150373973A1.

6 a) K. A. Watanabe, E. A. Falco and J. J. Fox, J. Am. Chem. Soc., 1972, 94, 3272. b) F. W. Lichtenthaler, T. Morino, W. Winterfeldt and Y. Sanemitsu, Tetrahedron Lett., 1975, 16, 3527.

7 M. T. Migawa, L. M. Risen, R. H. Griffey and E. E. Swayze, Organic Letters, 2005, 7, 3429.

8 L. Thiry, J. Gen. Vir., 1968, 2, 143.

9 J. M. Clark and J. K. Gunther, Biochim. Biophys. Acta, 1963 , 76, 636.

10 A. R. Burkett, K. K. Schlender and H. M. Sell, Phytochemistry, 1970, 9, 545.

11 a) U. Niedballa and H. Vorbrüggen, Angew. Chem. Int. Ed. Engl., 1970, 9, 461. b) Comprehensive Organic Name Reactions and Reagents, 2010, 2915.

12 M. Sakagami and H. Hamana, Tetrahedron Lett., 2000, 41, 5547.
13 H. Vorbrüggen and K. Krolikiewicz, Angew. Chem., Int. Ed., 1975, 14, 421

14 U. Niedballa and H. Vorbrüggen, Angew. Chem., Int. Ed., $1970,9,461$

15 N. Tzioumaki, S. Manta, E. Tsoukala, J. Vande Voorde, S. Liekens, D. Komiotis and J. Balzarini, Eur J Med Chem, 2011, 46, 993.

16 Q. Zhang, J. Sun, Y. Zhu, F. Zhang and B. Yu, Angew. Chem. Int. Ed. Engl., 2011, 50, 4933.

17 J. Zeng, Y. Liu, W. Chen, X. Zhao, L. Meng and Q. Wan, Top. Curr. Chem., 2018, 376, 27.

18 a) S. Norsikian, C. Tresse, M. François-Eude, L. JeanneJulien, G. Masson, V. Servajean, G. Genta-Jouve, J. M. Beau and E. Roulland, Angew. Chem, Int. Ed., 2020, 59, 6612. b) C. Tresse, M. François-Heude, V. Servajean, R. Ravinder, C. Lesieur, L. Geiben, L. Jeanne-Julien, V. Steinmetz, P. Retailleau, E. Roulland, J.-M. Beau and S. Norsikian, Chem. Eur. J., 2021, doi.org/10.1002/chem.202005102

19 a) D. D'Alonzo, A. Guaragna, A. Van Aerschot, P. Herdewijn and G. Palumbo, J. Org. Chem., 2010, 75, 6402. b) N. Bomholt, P. T. Jorgensen and E. B. Pedersen, Bioorg. Med. Chem. Lett., 2011, 21, 7376. c) L. Chanteloup and J.-M. Beau, Tetrahedron Lett., 1992, 33, 5347.

20 A.-T. Tran, R. A. Jones, J. Pastor, J. Boisson, N. Smith and M. C. Galan, Adv. Synth. Catal., 2011, 353, 2593.

21 A. Brar and Y. D. Vankar, Tetrahedron Lett., 2006, 47, 5207.

22 S. Liu and K. J. Edgar, Biomacromolecules, 2015, 16, 2556.

23 L. A. Carpino, H. Imazumi, B. M. Foxman, M. J. Vela, P. Henklein, A. El-Faham, J. Klose and M. Bienert, Org. Lett., 2000, 2, 2253

24 S. Norsikian, M. Beretta, A. Cannillo, A. Martin, P. Retailleau and J.-M. Beau, Chem. Commun., 2015, 51, 9991.

25 Prepared according to J. Pietruszka and A. Witt, Synthesis, 2006, 4266 using tosylazide.

26 For recent reviews see : a) V. K. Tiwari, B. B. Mishra, K. B. Mishra, N. Mishra, A. S. Singh and X. Chen, Chem. Rev., 2016, 116, 3086. b) S. Neumann, M. Biewend, S. Rana and W. H. Binder, Macromol. Rapid Commun., 2020, 41, e1900359.

27 Peaks in ${ }^{1} \mathrm{H}-\mathrm{NMR}$ spectrum broad and split due to the presence of $N$-Boc rotamers

28 Peaks in ${ }^{13} \mathrm{C}$-NMR spectrum broad and split due to the presence of $N$-Boc rotamers. 